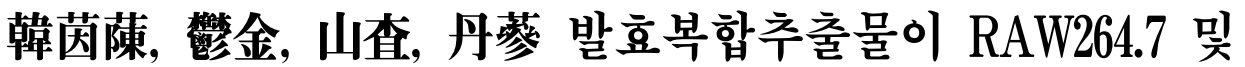 HUVEC 세포에서 나타나는 이상지질혈증 관련 염증인자 발현 및 항산화에 미치는 영향
}

이강욱, 조현경, 유호룡, 설인찬, 김윤식

대전대학교 한의과대학 심계내과학교실

\section{The Effects of an Extract of Fermented Artemisiae Iwayomogii Herba, Curcumae Longae, Crataegi Fructus and Salviae Miltiorrhizae Radix on Anti-inflammation Associated with Dyslipidemia and Anti-oxidation in RAW264.7 and HUVEC Cells}

Kang-wook Lee, Hyun-kyoung Cho, Ho-ryong Yoo, In-chan Seol, Yoon-sik Kim

Dept. of Circulatory Internal Medicine, College of Korean Medicine, Dae-Jeon University

\section{ABSTRACT}

Objectives: To investigate the effect of fermented extract of Artemisiae Iwayomogii Herba, Curcumae Longae, Crataegi Fructus and Salviae Miltiorrhizae Radix (FMH) on anti-inflammation associated with dyslipidemia and anti-oxidation in RAW264.7 and HUVEC cells.

Methods: The total polyphenols, total flavonoids, DPPH radical scavenging activity, ABTS radical scavenging activity, and cytotoxicity of FMH were measured. RAW264.7 cells treated with FMH were tested for production of NO, and for cytokine and LTB4 levels and HUVEC cells treated with FMH were examined for production of cDNA of genes related to inflammation.

Results:

1. FMH contained polyphenols and flavonoids. The DPPH and ABTS radical scavenging activity of FMH increased in a concentration-dependent manner.

2. FMH treatment inhibited the production of nitric oxide (NO), cytokines, and LTB4 in RAW264.7 cell when compared to the untreated control group.

3. FMH decreased the transcription of pro-inflammatory genes, whereas it increased transcription of anti-inflammatory genes, in HUVEC cells.

Conclusion: FMH is effective as an antioxidant and for treatment and prevention of dyslipidemia, atherosclerosis, ischemic heart disease, stroke, and other cardiocerebrovascular diseases.

$\overline{\text { Key words: }}$ Artemisiae Iwayomogii Herba, Curcumae Longae, Crataegi Fructus and Salviae Miltiorrhizae Radix, fermentation

\section{I. 서 론}

· 투고일: 2018.07.30, 심사일: 2018.09.26, 게재확정일: 2018.09.28

- 교신저자: 김윤식 충남 천안시 서북구 노태산로 4 대전대 부속 천안한방병원

TEL: 041-521-7536 FAX: 041-521-7007

E-mail: yoonsik@dju.kr
2016년 사망원인통계에 따르면 암에 이어 2, 3위 를 차지하는 주요 사망원인이 심장질환과 뇌혈관 질환으로, 특히 심장질환으로 인한 사망은 꾸준히 
증가하는 추세이다 ${ }^{1}$. 심뇌혈관질환 위험인자에는 고혈압, 당뇨, 이상지질혈증, 흡연, 비만 등이 있으 며 이중 고혈압의 유병률은 크게 변화가 없는 반 면 당뇨병, 이상지질혈증, 비만은 증가하고 있다 ${ }^{2}$ 우리나라의 심뇌혈관질환으로 인한 사망 중 동맥 경화성 질환이 가장 많으며, 그 중 죽상동맥경화증 이 임상적으로 큰 의의를 갖는다. 죽상동맥경화가 발생하면 혈관 내막에 콜레스테롤 침착과 세포증 식이 일어나 혈관내경이 좁아지게 되며 이는 말초 로의 혈액순환장애를 초래하여 허혈성 심장질환이 나 뇌경색 등을 유발하는데, 이상지질혈증은 이러 한 동맥경화의 위험성을 뚜렷이 증가시키는 것으 로 증명되었다. 이상지질혈증은 혈청콜레스테롤이 나 트리글리세리드가 비정상적인 높은 수치를 나 타내거나 high density lipoprotein(HDL)-cholesterol 이 비정상적인 낮은 수치를 나타내는 질환으로, 자 각증상이 없지만 방치하면 동맥경화성 질환을 유 발하고 특히 관상동맥질환의 가장 중요한 독립적 위험인자로서 위험하여 이를 조기에 발견하고 치 료하는 것이 중요하고 이를 위해 생활습관을 교정 하고 약물을 적절히 사용할 필요가 있다 4.5 .

약물로는 주로 스타틴 계열이 사용되는데, 최근 스타틴이 당뇨병 신규 발생을 증가시킨다는 연구 결과가 있으며, 인지기능 저하가 관찰되었다는 보 고가 있다 ${ }^{2}$ 이러한 부작용 때문에 이상지질혈증에 대한 한약물 치료 연구도 꾸준히 이루어지고 왔으 며, 처방으로 加味地黃湯 ${ }^{6}$, 凉膈散火湯 ${ }^{7}$ 등이 있고 단일약재로도 다양한 연구가 진행되어 그 유효성 을 밝힌 바 있다 ${ }^{8}$. 그 중 한인진과 울금은 복합추출 물로도 연구된 바 있으며 ${ }^{9}$ 이를 기초로 단일약재들 을 가미한 연구가 지속적으로 나오고 있다 ${ }^{10-13}$.

이상지질혈증은 한의학적으로 痰濁, 血瘀의 범 주에 속하며 ${ }^{14}$, 이상지질혈증이 유발하는 동맥경화 증 또한 痰飲, 瘀血, 寒凝, 氣滯, 虛勞 등의 범주에 속한다 ${ }^{3}$. 痰飲의 개념 중 체내에 들어온 水液이 정 상적으로 운화되지 못해 전신에 고루 분포하지 못 하는 것, 瘀血의 개념 중 혈액자체의 성분이 바뀌
어서 유속과 생리기능에 이상이 생긴 혈액, 혈관의 병변으로 혈전들이 생겨 혈류가 불창한 것 등 $^{15}$ 이 이상지질혈증의 개념과 유사하다고 볼 수 있다.

발효는 오래전부터 인류가 자연에서 발견한 유 용한 기술로서, 미생물작용을 이용하여 식품에 좋 은 향, 맛, 조직감 등을 부여하고 유효성분 증진작 용 및 유효성분을 더 작은 단위로 분해하여 쉽게 장관에 흡수될 수 있게 하는 작용을 하며, 비위기 능이 떨어지는 사람들에게도 적합하다 ${ }^{16}$.

이상지질혈증에 대한 단일 발효 한약재 연구는 발효백하수오 ${ }^{17}$, 솔잎발효액 ${ }^{18}$ 등 다수가 있으나 발 효 한약재들의 복합추출물에 대한 연구는 부족한 실정이다.

본원 한방병원에서 이상지질혈증치료를 위해 사 용하고 있는 청혈플러스는 韓茵蔯, 鬱金, 山査, 丹 苶으로 이루어져 있으며, 유의한 효능이 있는 것으 로 기존에 연구된 바 있다 ${ }^{19}$.

본 저자는 이에 착안하여 상기 청혈플러스 구성 발효 약재의 복합추출물이 이상지질혈증에 효과가 있는지를 규명하려는 의도로 실험적 연구를 진행하 게 되었으며, 유의성 있는 결과를 얻었기에 보고한다.

\section{II. 재료 및 방법}

1. 재 료

1) 약 재

본 실험에 사용한 한인진, 울금, 산사, 단삼은 (주) 옴니허브에서 구입하여 대전대학교 TBRC-RIC에 서 정선 후 사용하였다.

2) 시 약

사용된 시약은 monosodium glutamate( $\mathrm{MSG}$ : Sigma, U.S.A.), glucose(Sigma, U.S.A.), dulbecco's Modified Eagle's Medium(DMEM : Gibco BRL, U.S.A.), EGM ${ }^{\mathrm{TM}}$-2 Medium(Lonza, Switzerland), EGM $^{\mathrm{TM}}$-2 SingleQuots ${ }^{\mathrm{TM}}$ Kit(Lonza, Switzerland), fetal bovine serum(FBS : Gibco BRL, U.S.A.), penicillin-streptomycin(Sigma, U.S.A.), antibiotic-antimycotic 


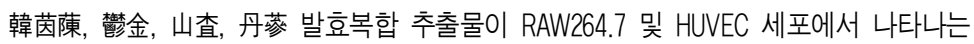
이상지질혈증 관련 염증인자 발현 및 항산화에 미치는 영향

(Sigma, U.S.A.), trypan blue(Sigma, U.S.A.), EZ-Cytox (Daeilab, Korea), lipopolysaccharide(LPS : Sigma, U.S.A.), hydrogen peroxide(H202 : Sigma, U.S.A.), nitric oxide detection kit(Intron Biotechnology, Korea), mouse cytokine milliplex map immunoassay kit(Millipore, U.S.A.), LTB4 Parameter Assay Kit (R\&D systems Co., U.S.A.), dulbecco's phosphate buffered saline(D-PBS : Welgene, Korea), 1,1diphenyl-2-picryl-hydrazyl(DPPH : Sigma, U.S.A.), 2,2'-azinobis-(3-ethylbenzothiazoline-6-sulfonic acid)(ABTS : Sigma, U.S.A.), folin-Ciocalteu's phenol reagent(Merck., Germany), gallic acid(Sigma, U.S.A.), quercertin(Sigma, U.S.A.), sodium carbonate (Sigma, U.S.A.), aluminum nitrate nonahydrate (Sigma, U.S.A.), potassium acetate solution(Sigma, U.S.A.), (2,7)-dichlorodihydrofluorescin diacettate (DCFH-DA : Sigma, U.S.A.), Total RNA prep kit(Intronbio, Korea), AccuPower CycleScript RT PreMix(Bioneer, Korea), SYBR Green(Qiagen, Germany), DEPC-DW(Bioneer Co., Korea)등이다.

3) 기 기

사용된 기기는 rotary vacuum evaporator(Büchi B-480, Switzerland), freeze dryer(EYELA FDU-540, Japan), CO2 incubator(Forma scientific Co., U.S.A.), clean bench(Vision scientific, Korea), autoclave(Sanyo, Japan), vortex mixer(Vision scientific, Korea), centrifuge (Hanil, Korea), deep-freezer(Sanyo, Japan), ice-maker (Vision scientific, Korea), plate shaker(Lab-Line, U.S.A.), luminex(Millipore, U.S.A.), micro plate reader (Molecular Devices, U.S.A.), flow cytometer(Becton Dickinson, U.S.A.), Nanodrop(Thermofisher, U.S.A.), Alpha Cycler 1 PCRmax(PCRmax, U.K.) real time PCR( Qiagen, Germany)등이다.

\section{2. 방 법}

1) 시료 추출 및 발효

한인진, 울금, 산사, 단삼 각각 $30 \mathrm{~g}$ 에 증류수
$2000 \mathrm{ml}$ 를 넣어 3시간 동안 환류추출을 한 후 여과 액에 고초균(Bacillus subtilis) 과, 젖산균(Lactobacillus platarum)을 이용한 혼합발효를 진행하였다(Fig. 1). 이후 발효된 물질을 rotary vacuum evaporator 로 감압 농축하였으며, 농축된 용액을 freeze dryer로 동결 건조하여 얻어낸 발효복합추출물(fermentation mixed herbs extract 이하, FMH) 분말 $24.31 \mathrm{~g}$ (수율 $20.26 \%)$ 을 초저온 냉동고 $\left(-80{ }^{\circ} \mathrm{C}\right)$ 에서 보관하며 실험에 필요한 농도로 증류수에 희석해 사용하였다.

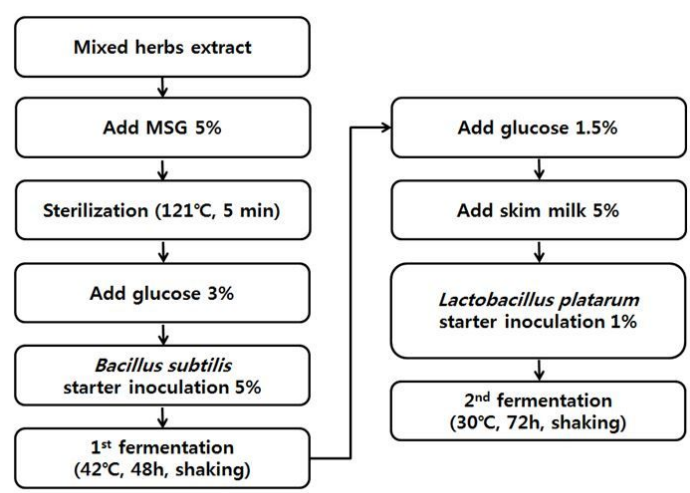

Fig. 1. Mixed fermentation process of FMH.

2) 항산화 효능평가

(1) 총 polyphenol 함량 측정

FMH 1 ml에 50\% Foiln-Ciocalteu's phenol reagent $0.5 \mathrm{ml}$ 를 가하여 실온에서 3 분간 반응시켰 다. 반응용액에 $\mathrm{Na} 2 \mathrm{CO} 3$ 포화용액 $1 \mathrm{ml}$ 와 $7.5 \mathrm{ml}$ 증류수를 차례로 혼합하여 30 분간 정치시킨 뒤, $14,000 \mathrm{~g}$ 에서 10 분간 원심분리한 후 상등액을 취해 $760 \mathrm{~nm}$ 파장에서 흡광도를 측정하였다. 총 phenol 함량은 gallic acid를 표준물질로 이용하여 작성한 검량선에 따라 함량을 구하였다.

(2) 총 flavonoid 함량 측정

$\mathrm{FMH} 0.1 \mathrm{ml}$ 과 $80 \%$ 에탄올 $0.9 \mathrm{ml}$ 을 혼합한 혼합 물 $0.5 \mathrm{ml}$ 에 10\% aluminium nitrate와 $1 \mathrm{M}$ potassium acetate $0.1 \mathrm{ml}$ 그리고 $80 \%$ 에탄올 $4.3 \mathrm{ml}$ 을 가하 여 실온에 40 분 방치한 뒤 $415 \mathrm{~nm}$ 파장에서 흡광 도를 측정하였으며, quercetin을 이용하여 작성한 
표준곡선으로부터 함량을 구하였다.

(3) $\mathrm{DPPH}$ radical 소거능 측정

$\mathrm{FMH}$ 의 최종 농도가 $1,10,100,1,000(\mu \mathrm{g} / \mathrm{ml})$ 의 농도로 될 수 있게 희석시켰으며, 에탄올에 용해시 킨 $0.2 \mathrm{mM}$ 의 DPPH 용액 $150 \mu \mathrm{l}$ 와 $\mathrm{FMH}$ 를 각각 $100 \mu 1$ 씩 혼합하여 $37{ }^{\circ} \mathrm{C}$ 에서 30 분간 반응 시켰다. 반응 후 $517 \mathrm{~nm}$ 파장에서 흡광도를 측정하였다. 시료액의 대조군은 증류수를 넣었으며, $\mathrm{DPPH}$ 용 액의 대조군으로서는 에탄올을 넣어 보정값을 얻 었다. 그 후 DPPH radical 소거율((대조군의 흡광 도-시료 첨가군의 흡광도) $\times 100 /$ 대조군의 흡광도) 을 계산하였다.

(4) ABTS radical 소거능 측정

$\mathrm{FMH}$ 의 최종 농도가 $1,10,100,1,000(\mathrm{\mu g} / \mathrm{ml})$ 의 농도로 될 수 있게 희석시켰으며, ABTS 용액은 7.4 mM ABTS(2,2-azino-bis-(3-ethylbenzothiazoline -6-sulfonic acid))와 $2.6 \mathrm{mM}$ potassium persulphate 를 제조한 후, 암소에 하루 동안 방치하여 양이온 $(\mathrm{ABTS} \cdot+)$ 을 형성시킨 다음 $732 \mathrm{~nm}$ 에서 흡광도 를 측정하여 흡광도 값이 1.5 이하가 나오도록 희 석하고, 희석된 $\mathrm{ABTS} \cdot+$ 용액 $150 \mu \mathrm{l}$ 와 $\mathrm{FMH}$ 를 각 각 $5 \mu \mathrm{l}$ 혼합하고, 실온에서 10 분간 반응시킨 후, $732 \mathrm{~nm}$ 파장에서 흡광도를 측정하였다. 항산화능은 증류수를 대조군으로 하여 대조군에 대한 ABTS radical 소거율(시료 첨가군의 흡광도 $\times 100 /(1$-대조 군의 흡광도))을 백분율로 나타내었다.

3) 세포 배양

RAW264.7 세포는 10\% fetal bovine serum(FBS) 와 $1 \%$ penicillin-streptomycin으로 조성된 $\mathrm{DMEM}$ 배지를 사용하였으며, human umbilical vein endothelial cell(HUVEC) 세포는 $\mathrm{EGM}^{\mathrm{TN}}$-2 Medium과 EGM ${ }^{\mathrm{TM}}$-2 SingleQuots ${ }^{\mathrm{TM}} \mathrm{Kit}$ 으로 혼합된 배지를 사용하여 $37{ }^{\circ} \mathrm{C}$, $5 \% \mathrm{CO} 2$ 조건이 유지되는 세포배양기에서 배양하 였으며, 2-3일 주기로 계대 배양하여 실험을 진행 하였다.

4) 세포 생존율 측정

96 well plate에 RAW264.7 세포와 HUVEC 세
포를 $1.5 \times 105$ cells/well로 분주하여 24 시간 동안 배 양 하였다. 실험을 하기 전에 새로운 배양액으로 교체하였고, $\mathrm{FMH}$ 를 각각 $1,10,100(\mu \mathrm{g} / \mathrm{ml})$ 의 농 도로 처리하여 다시 24시간 동안 배양하였다. 배양 후 $10 \mu \mathrm{l}$ 의 EZ-Cytox 용액을 첨가하여 세포배양기 에서 30 분간 반응시켰다. 반응 후 $450 \mathrm{~nm}$ 에서 흡 광도의 변화를 측정하여 대조군에 대한 세포 생존 율을 백분율로 표시 하였다.

5) 항염증 효능평가

(1) 세포 내 nitric oxide( $\mathrm{NO}$ ) 생성량 측정

96 well plate에 RAW264.7 세포를 1.5×105 cells/well 로 분주하여 24시간 동안 배양 하였다. 배양 후 새 로운 배양액으로 교체하였으며, FMH 1, 10, 100 $(\mu \mathrm{g} / \mathrm{ml})$ 의 농도와 $1 \mu \mathrm{g} / \mathrm{ml}$ LPS를 함께 처리하여 다시 24시간 동안 배양하였다. 이 후, N1 buffer를 $50 \mu l$ 씩 각 well에 처리하여 10 분간 상온에서 반응 한 후, N2 buffer를 $50 \mu \mathrm{l}$ 씩 각 well에 처리하고 10 분간 반응시켰다. 반응 후 $540 \mathrm{~nm}$ 파장에서 흡광 도를 측정한 뒤 대조군에 대한 백분율로 나타내었다.

(2) 세포 내 cytokine 생성량 측정

12 well plate에 RAW264.7 세포를 2×105 cells/well 로 분주하여 24시간 동안 배양 하였다. 배양 후 새 로운 배양액으로 교체하였으며, $\mathrm{FMH} \mathrm{1,10,100}$ $(\mu \mathrm{g} / \mathrm{ml})$ 의 농도와 $1 \mu \mathrm{g} / \mathrm{ml} \mathrm{LPS}$ 를 함께 처리하여 다시 24시간 동안 배양하였다. 이후, 배양액을 $1,200 \mathrm{rpm}$ 에서 5 분간 원심분리하여 얻은 상등액과 standard를 96 well plate에 $25 \mu$ 씩 분주하고 assay buffer 및 matrix buffer, antibody-immobilized beads 를 각 $25 \mu 1$ 씩 가하여 혼합한 후 2시간 동안 실온 에서 반응시키고, washing 완충 용액을 이용하여 2 회 세척하였다. 세척 후 $25 \mu l$ 의 detection antibody 을 가하여 1 시간 동안 실온에서 반응시키고 추가 로 $25 \mu$ l의 Streptavidin-Phycoerythrin을 가하여 30 분 동안 실온에서 반응시킨 뒤 washing 완충 용액 을 이용하여 2회 세척하였다. 세척 후 $\mathrm{PBS}$ 를 150 ul 넣고 5 분 간 shaking한 후 Luminex를 이용하여 측정한 결과를 절대 값으로 표시하였다. 


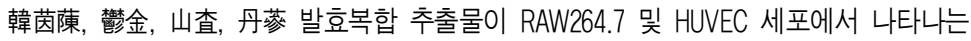
이상지질혈증 관련 염증인자 발현 및 항산화에 미치는 영향

(3) 세포 내 leukotriene B4(LTB4)생성량 측정

12 well plate에 RAW264.7 세포를 $2 \times 105$ cells/well 로 분주하여 24시간 동안 배양 하였다. 배양 후 새 로운 배양액으로 교체하였으며, FMH 1, 10, 100 $(\mu \mathrm{g} / \mathrm{ml})$ 의 농도와 $1 \mu \mathrm{gg} / \mathrm{ml} \mathrm{LPS}$ 를 함께 처리하여 다시 24시간 동안 배양하였다. 이후, 배양액을 $1,200 \mathrm{rpm}$ 에서 5 분간 원심분리하여 얻은 상등액과 standard를 96 well plate에 $100 \mu \mathrm{l}$ 씩 넣고 $37{ }^{\circ} \mathrm{C}$ 에 서 90 분간 반응시켰다. 반응 후 washing buffer를 이용하여 3 회 세척 작업을 진행한 후 $100 \mu l$ 의 detection antibody를 넣어 다시 $37{ }^{\circ} \mathrm{C}$ 에서 60 분간 반응시키고 세척하였다. 세척 후 HRP conjugate를 $100 \mu 1$ 씩 넣어 $37{ }^{\circ} \mathrm{C}$ 에서 30 분간 반응시키고 세척 한 뒤 substrate reagent를 $90 \mu \mathrm{l}$ 씩 넣어 $37{ }^{\circ} \mathrm{C}$ 에서 15 분간 반응시키고 $50 \mu$ l의 stop solution을 추가하 여 ELISA reader기를 통해 $450 \mathrm{~nm}$ 에서 흡광도를 측정하였으며, standard curve를 기준으로 절대 값 으로 표시하였다.

6) 세포 내 유전자 발현량 측정

(1) RNA 추출

6 well plate에 HUVEC 세포를 106 cells/well로 분주하여 24시간 동안 배양하였다. 배양 후 새로운 배양액으로 교체하였으며, FMH 1, 10, $100(\mu \mathrm{g} / \mathrm{ml})$ 의 농도와 $1 \mu \mathrm{g} / \mathrm{ml} \mathrm{TNF-} \alpha$ 를 함께 처리하여 다시 24시간 동안 배양하였다. HUVEC 세포를 PBS로 2 회 씻어준 뒤 easy blue $1 \mathrm{ml}$ 와 chloroform $200 \mu \mathrm{l}$ 를 넣고 vortexing 해준 후 $13,000 \mathrm{rpm}, 4{ }^{\circ} \mathrm{C}$ 에서 10 분 동안 원심분리 하였다. 그 후 상층액 $400 \mu \mathrm{l}$ 와 binding buffer $400 \mu \mathrm{l}$ 를 실온에서 1분 동안 반응시 킨 뒤 반응액 $700 \mu 1$ 를 column에 주입하여 13,000 $\mathrm{rpm}$ 에서 30초 동안 원심분리 하였다. Column에 washing buffer $\mathrm{A}$ 를 $700 \mu \mathrm{l}$ 넣고 13,000 rpm에서 30 초 동안 원심분리 후 washing buffer B를 $700 \mu \mathrm{l}$ 넣 고 동일하게 원심분리 하였다. Column 하단을 $\mathrm{Ep}$ tube로 교체한 후 column에 elution buffer를 $50 \mu \mathrm{l}$ 넣고 1 분 동안 반응시킨 뒤 $13,000 \mathrm{rpm}$ 에서 1 분 동 안 원심분리하여 추출된 total RNA를 모았다.
(2) $\mathrm{cDNA}$ 합성

역전사(reverse transcription) 반응은 RT premix kit의 mixture(reaction buffer, dNTPs mixture, RNase inhibitor, stabilizer, oligo dT15 primer)를 사용하여 total RNA $1 \mu \mathrm{g}$ 이 되도록 diethyl pyrocarbonate (DEPC) 처리된 증류수에 최종 부피가 $20 \mu$ 가 되도 록 하여 첨가하였다. 이 $20 \mu \mathrm{l}$ 의 반응 혼합액을 잘 섞 은 뒤 $45{ }^{\circ} \mathrm{C}$ 에서 60 분 반응시켜 first-strand $\mathrm{cDNA}$ 를 합성한 후 $95{ }^{\circ} \mathrm{C}$ 에서 5 분 동안 방치하여 $\mathrm{M}-\mathrm{MLV}$ $\mathrm{RT}$ 를 불활성화 시킨 다음 합성이 완료된 $\mathrm{cDNA}$ 를 polymerase chain reaction (PCR)에 사용하였다.

(3) 유전자 발현량 측정

합성이 완료된 $\mathrm{cDNA}$ 를 증폭시키기 위하여 real-time $\mathrm{PCR}$ 을 진행하였으며, real-time 전용 tube에 $\mathrm{cDNA}$ $1 \mu \mathrm{l}$, 각 primer $2 \mu \mathrm{l}$, SYBR Green $10 \mu \mathrm{l}, \mathrm{DEPC}-\mathrm{DW}$ $5 \mu 1$ 씩 넣어 다음과 같이 진행하였다. $94{ }^{\circ} \mathrm{C}$ 에서 5 분 동안 반응한 다음 $94{ }^{\circ} \mathrm{C}$ 에서 15 초, $60{ }^{\circ} \mathrm{C}$ 에서 30 초, $72{ }^{\circ} \mathrm{C}$ 에서 30 초를 40 회 반복하여 진행하였고 이 후 유전자 발현량은 대조군에 비하여 계산하였으며, 사용된 primer의 sequence는 Table 1과 같다.

Table 1. The Sequences of Primers in This Study

\begin{tabular}{|c|c|c|}
\hline Primer & $\mathrm{F} / \mathrm{R}^{*}$ & Sequences \\
\hline \multirow{2}{*}{ GAPD H } & F & GGCAAATTCCATGGCACCG \\
\hline & $\mathrm{R}$ & TCGCCCCACTTGATTTTGGA \\
\hline \multirow{2}{*}{ CCL5 } & $\mathrm{F}$ & CGGGAGTACATCAACTCTTTGGA \\
\hline & $\mathrm{R}$ & CAAGCTAGGACAAGAGCAAGCA \\
\hline \multirow{2}{*}{ MCP-1 } & & GCTCAGCCAGATGCAATCAA \\
\hline & & CTTGGCCACAATGGTCTTGA \\
\hline \multirow{2}{*}{ CXCL8 } & & TCTTGGCAGCCTTCCTGATT \\
\hline & & TTTCTGTGTTGGCGCAGTGT \\
\hline \multirow{2}{*}{ CX3CL1 } & & TCACGTGCAGCAAGATGACA \\
\hline & & TCCTTGACCCATTGCTCCTT \\
\hline \multirow{2}{*}{ ICAM-1 } & & TCTTCCTCGGCCTTCCCATA \\
\hline & & AGGTACCATGGCCCCAAATG \\
\hline \multirow{2}{*}{ VCAM-1 } & $\mathrm{F}$ & CCCTACCATTGAAGATACTGG \\
\hline & & ATCTCTGGGGGCAACATTGAC \\
\hline \multirow{2}{*}{ KLF2 } & $\mathrm{F}$ & CCTCCTTGACGAGTTTTGTTTTTC \\
\hline & $\mathrm{R}$ & AAGGCATCACAAGCCTCGAT \\
\hline \multirow{2}{*}{ eNOS } & & CTCATGGGCACGGTGATG \\
\hline & & ACCACGTCATACTCATCCATACAC \\
\hline
\end{tabular}

* $\mathrm{F}$ : forward, $\mathrm{R}$ : reverse 


\section{3. 통계처리}

실험 결과는 SPSS 24.0의 unpaired student's T-test와 ANOVA를 사용하여 통계처리 하였고 $\mathrm{p}<0.05, \mathrm{p}<0.01$ 및 $\mathrm{p}<0.001$ 수준에서 그 유의성을 검정하였다.

\section{III. 실험 결과}

\section{1. 항산화 효능평가}

1) 총 polyphenol 함량 측정

Gallic acid를 표준물질로 하여 $\mathrm{FMH}$ 에 존재하 는 총 polyphenol 함량을 측정한 결과, $8.74 \pm 0.30$ $\mathrm{GAE} / \mathrm{g}$ 으로 나타났다(Table 2).

2) 총 flavonoid 함량 측정

Quercetin을 표준물질로 하여 $\mathrm{FMH}$ 에 존재하는 총 flavonoid 함량을 측정한 결과, $1.83 \pm 0.19 \mathrm{mg} / \mathrm{g}$ 으로 나타났다(Table 3).

Table 2. Total Polyphenol Contents of FMH

\begin{tabular}{cc} 
Sample & Total polyphenol (mg GAE*/g) \\
FMH & $8.74 \pm 0.30$ \\
\hline
\end{tabular}

The results were expressed as mean \pm S.D.

* Total phenol content was expressed as milligram of galic acid equivalent (GAE) per gram of extract.

Table 3. Total Flavonoid Contents of FMH

\begin{tabular}{cc} 
Sample & Total flavonoid $(\mathrm{mg} / \mathrm{g})$ \\
\hline FMH & $1.83 \pm 0.19$ \\
\hline The results were expressed
\end{tabular}

3) $\mathrm{DPPH}$ radical 소거능 측정

$\mathrm{FMH}$ 의 DPPH radical 소거능을 측정한 결과, 1 , $10,100,1,000(\mu \mathrm{g} / \mathrm{ml})$ 농도에서 각각 $1.03 \pm 0.30 \%$, $3.68 \pm 0.11 \%, 11.15 \pm 0.73 \%, 33.34 \pm 1.00 \%$ 로 나타나, $\mathrm{DPPH}$ radical 소거능의 농도 의존적인 증가가 나타났다 (Fig. 2).

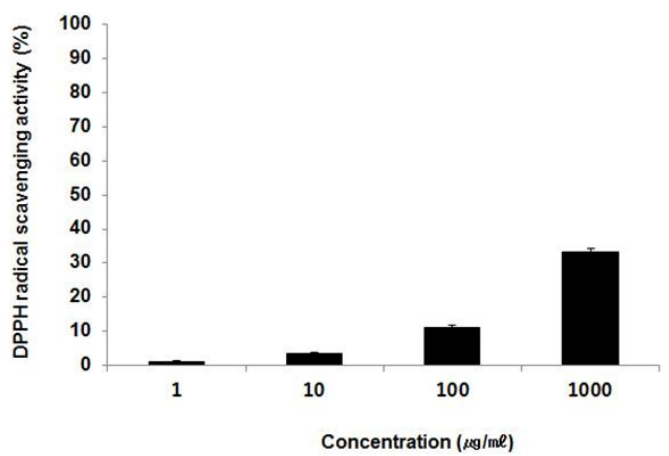

Fig. 2. DPPH radical scavenging activity of FMH.

FMH was incubated at $1,10,100$, and $1,000 \mu \mathrm{g} / \mathrm{ml}$ with DPPH solution for 30 mins. Activities were determined by measurement of absorbance at $517 \mathrm{~nm}$. The results were expressed as mean \pm S.D from three independent experiments.

4) ABTS radical 소거능 측정

$\mathrm{FMH}$ 의 ABTS radical 소거능을 측정한 결과, 1 , $10,100,1,000(\mu \mathrm{g} / \mathrm{ml})$ 농도에서 각각 $2.42 \pm 0.23 \%$, $4.64 \pm 0.26 \%, 11.08 \pm 0.61 \%, 43.66 \pm 0.14 \%$ 로 나타나, ABTS radical 소거능의 농도 의존적인 증가가 나타났다 (Fig. 3).

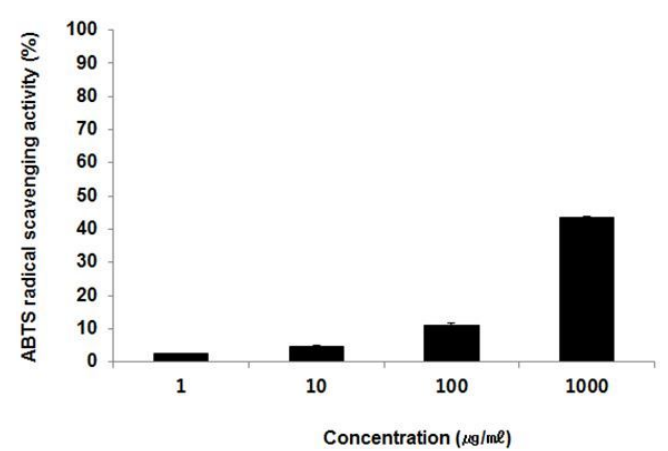

Fig. 3. ABTS radical scavenging activity of FMH.

FMH was incubated at $1,10,100$, and $1,000 \mu \mathrm{g} / \mathrm{ml}$ with ABTS solution for 10 mins. Activities were determined by measurement of absorbance at $732 \mathrm{~nm}$. The results were expressed as mean \pm S.D from three independent experiments. 


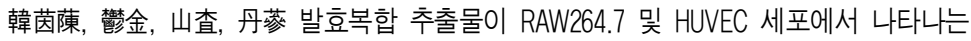
이상지질혈증 관련 염증인자 발현 및 항산화에 미치는 영향

\section{2. 세포생존율 측정}

RAW264.7 세포에서 세포생존율을 측정한 결과, 대조군이 $100.00 \pm 2.96 \%$ 로 나타났을 때, FMH 1, 10, $100,200 \mu \mathrm{g} / \mathrm{ml}$ 에서 각각 $106.85 \pm 3.33 \%, 109.36 \pm 2.43 \%$, $103.77 \pm 6.48 \%, 57.10 \pm 1.72 \%$ 로 나타났다(Fig. 4A).

HUVEC 세포에서 세포생존율을 측정한 결과, 대조군이 $100.00 \pm 2.19 \%$ 로 나타났을 때, $\mathrm{FMH} 1,10$, $100,200 \mu \mathrm{g} / \mathrm{ml}$ 에서 각각 $99.77 \pm 0.82 \%, 99.75 \pm 1.37 \%$, $99.96 \pm 1.16 \%, 73.16 \pm 1.91 \%$ 로 나타났다(Fig. 4B).
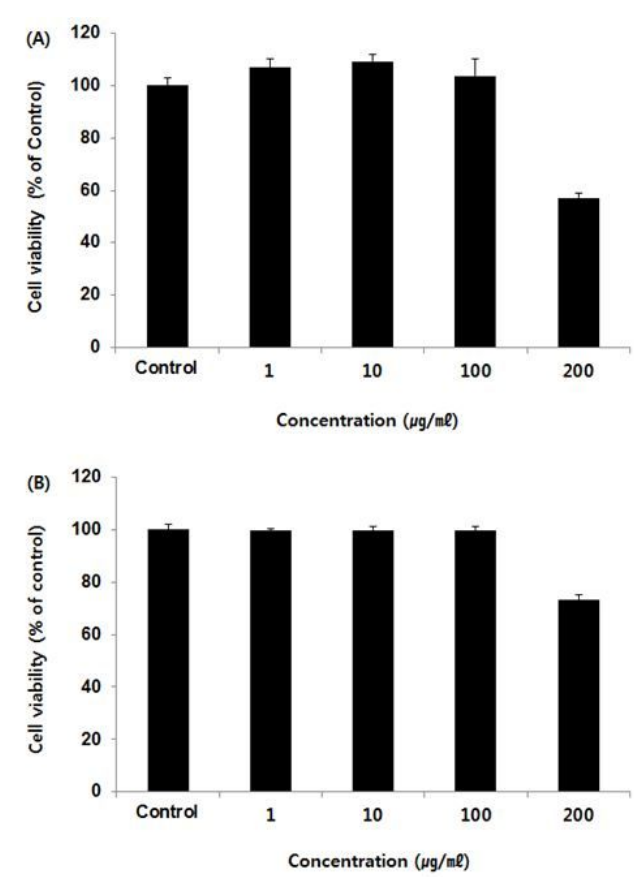

Fig. 4. Cell viability of RAW264.7 cells and HUVEC cells were treated FMH.

RAW264.7 cells and HUVEC cells were treated by $1,10,100$, and $200 \mu \mathrm{g} / \mathrm{ml}$ of FMH for $24 \mathrm{~h}$. Treated cells were exposed by EZ-Cytox for 30 min and then absorbance were measured at 450 $\mathrm{nm}$ using microplate reader. Cell viability were calculated as percentage versus control. The result were presented by the mean \pm S.D from three independent experiments.

(A) RAW264.7 cell, (B) HUVEC cell

\section{3. 항염증 효능평가}

1) 세포 내 NO 생성량 측정

RAW264.7 세포 내 NO 생성량을 측정한 결과, 정상군은 $21.92 \pm 2.80 \%$, 대조군은 $100.00 \pm 2.12 \%$ 로 나 타났을 때, FMH 1, 10, $100 \mu \mathrm{g} / \mathrm{ml}$ 에서 각각 $88.45 \pm$ $0.71 \%, 86.47 \pm 2.07 \%, 79.49 \pm 2.20 \%$ 로 나타나, 모든 농도 에서 대조군에 비해 유의성 있는(* : p $<0.05$, ** : p $<0.01)$ 감소가 나타났다(Fig. 5).

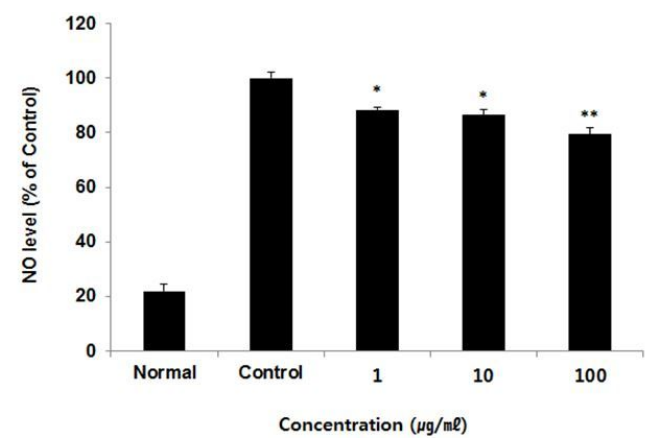

Fig. 5. Effect of FMH on NO level in RAW264.7 cells.

RAW264.7 cells were treated by 1,10 , and 100 $\mu \mathrm{g} / \mathrm{ml}$ of $\mathrm{FMH}$ with $1 \mu \mathrm{g} / \mathrm{ml}$ LPS for $24 \mathrm{~h}$. Treated cells were exposed by nitric oxide detection kit and then absorbance were measured at 540 $\mathrm{nm}$ using microplate reader. Level of $\mathrm{NO}$ were calculated as percentage versus control. The result were presented by the mean \pm S.D from three independent experiments (Significance of results, * : $\mathrm{p}<0.05,{ }^{* *}: \mathrm{p}<0.01$ compared to control).

2) 세포 내 cytokine 생성량 측정

(1) Interleukin $1 \beta(\mathrm{IL}-1 \beta)$

RAW264.7 세포 내 IL-1 생성량을 측정한 결 과, 정상군은 $46.05 \pm 0.82 \mathrm{pg} / \mathrm{ml}$, 대조군은 $123.34 \pm 3.27$ $\mathrm{pg} / \mathrm{ml}$ 로 나타났을 때, FMH 1, 10, $100 \mu \mathrm{g} / \mathrm{ml}$ 에서 각각 $120.85 \pm 1.52 \mathrm{pg} / \mathrm{ml}, 105.73 \pm 9.18 \mathrm{pg} / \mathrm{ml}, 97.01 \pm 0.51$ $\mathrm{pg} / \mathrm{ml}$ 로 나타나, $10,100 \mu \mathrm{g} / \mathrm{ml}$ 농도에서 대조군에 비해 유의성 있는(* : $\left.\mathrm{p}<0.05,{ }^{* * *}: \mathrm{p}<0.001\right)$ 감소 가 나타났다(Fig. 6). 


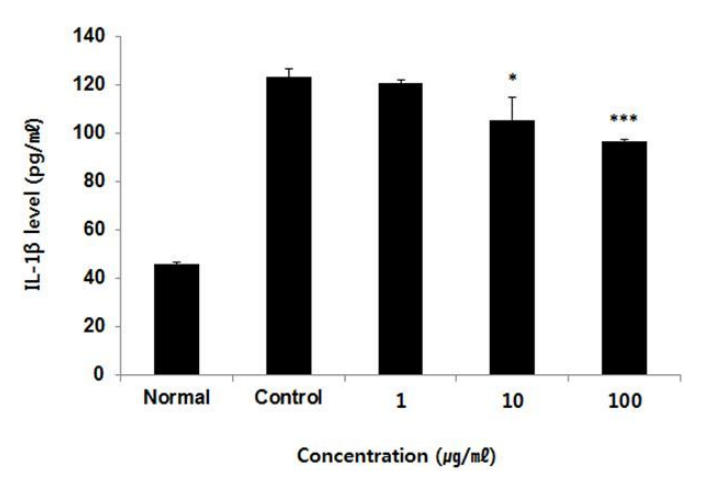

Fig. 6. Effect of FMH on IL-1B level in RAW264.7 cells.

RAW264.7 cells were treated by 1,10 , and 100 $\mu \mathrm{g} / \mathrm{ml}$ of $\mathrm{FMH}$ with $1 \mu \mathrm{g} / \mathrm{ml}$ LPS for $24 \mathrm{~h}$. Treated cells were measured by mouse cytokine milliplex map immunoassay kit. The result were presented by the mean \pm S.D from three independent experiments (Significance of results, * : p< 0.05 , *** : p<0.001 compared to control).

(2) Interleukin 6(IL-6)

RAW264.7 세포 내 IL-6 생성량을 측정한 결과, 정상군은 $116.80 \pm 27.32 \mathrm{pg} / \mathrm{ml}$, 대조군은 $151839.83 \pm 2593.07$ $\mathrm{pg} / \mathrm{ml}$ 로 나타났을 때, $\mathrm{FMH} \mathrm{1,} \mathrm{10,} 100 \mu \mathrm{g} / \mathrm{ml}$ 에서 각각 $106293.60 \pm 18652.25 \mathrm{pg} / \mathrm{ml}, \quad 91706.27 \pm 9382.48$ $\mathrm{pg} / \mathrm{ml}, 81373.25 \pm 12175.46 \mathrm{pg} / \mathrm{ml}$ 로 나타나, 모든 농 도에서 대조군에 비해 유의성 있는(* : $\mathrm{p}<0.05$, ** : $\mathrm{p}<0.01$,*** : $\mathrm{p}<0.001$ ) 감소가 나타났다(Fig. 7).

(3) Tumor necrosis factor $a(\mathrm{TNF}-\mathrm{a})$

RAW264.7 세포 내 TNF- $a$ 생성량을 측정한 결과, 정상군은 $8088.67 \pm 174.67 \mathrm{pg} / \mathrm{ml}$, 대조군은 15005.33 $\pm 346.69 \mathrm{pg} / \mathrm{ml}$ 로 나타났을 때, $\mathrm{FMH} \mathrm{1,} \mathrm{10,} 100 \mu \mathrm{g} / \mathrm{ml}$ 에서 각각 $14033.67 \pm 792.87 \mathrm{pg} / \mathrm{ml}, 12661.25 \pm 316.43$ $\mathrm{pg} / \mathrm{ml}, 11670.67 \pm 346.43 \mathrm{pg} / \mathrm{ml}$ 로 나타나, $10,100 \mu \mathrm{g} / \mathrm{ml}$ 농도에서 대조군에 비해 유의성 있는(* : $\mathrm{p}<0.05$, ** : p $<0.01$ ) 감소가 나타났다(Fig. 8).

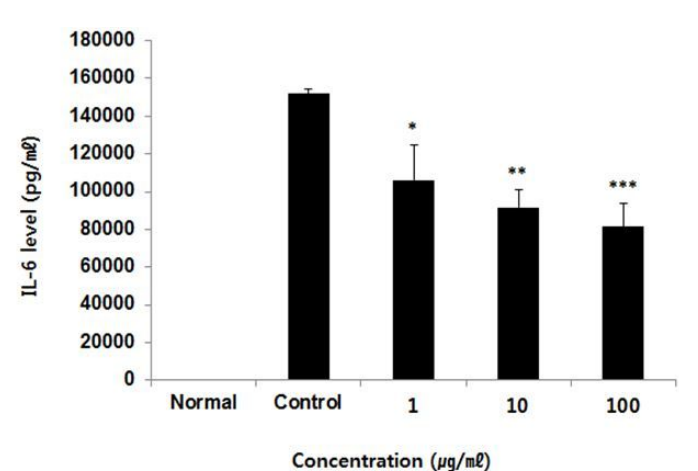

Fig. 7. Effect of FMH on IL-6 level in RAW264.7 cells.

RAW264.7 cells were treated by 1,10 , and 100 $\mu \mathrm{g} / \mathrm{ml}$ of FMH with $1 \mu \mathrm{g} / \mathrm{ml}$ LPS for $24 \mathrm{~h}$. Treated cells were measured by mouse cytokine milliplex map immunoassay kit. The result were presented by the mean \pm S.D from three independent experiments (Significance of results, * : $\mathrm{p}<0.05,{ }^{* *}: \mathrm{p}<0.01,{ }^{* * *}: \mathrm{p}<0.001$ compared to control).

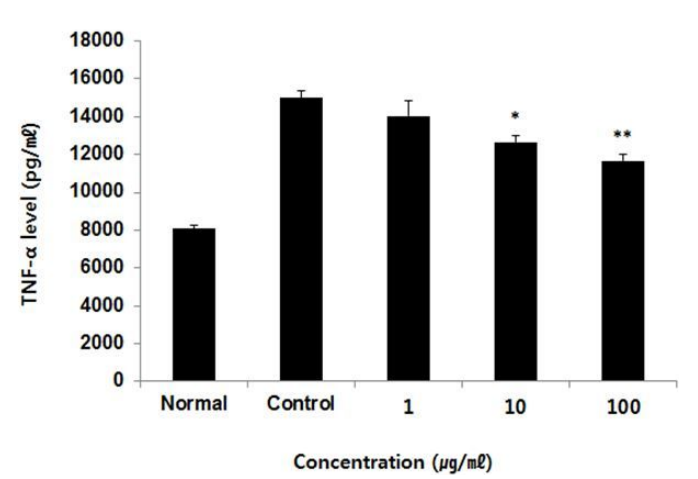

Fig. 8. Effect of FMH on TNF-a level in RAW264.7 cells.

RAW264.7 cells were treated by 1,10 , and 100 $\mu \mathrm{g} / \mathrm{ml}$ of $\mathrm{FMH}$ with $1 \mu \mathrm{g} / \mathrm{ml}$ LPS for $24 \mathrm{~h}$. Treated cells were measured by mouse cytokine milliplex map immunoassay kit. The result were presented by the mean \pm S.D from three independent experiments (Significance of results, ${ }^{*}: \mathrm{p}<0.05$, ** : $p<0.01$ compared to control).

3) 세포 내 LTB4 생성량 측정

$\mathrm{RAW} 264.7$ 세포 내 LTB4 생성량을 측정한 결과, 정상군은 $15.06 \pm 1.19 \mathrm{pg} / \mathrm{ml}$, 대조군은 $102.15 \pm 2.36$ 


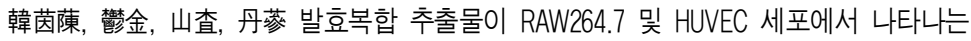
이상지질혈증 관련 염증인자 발현 및 항산화에 미치는 영향

$\mathrm{pg} / \mathrm{ml}$ 로 나타났을 때, FMH 1, 10, $100 \mu \mathrm{g} / \mathrm{ml}$ 에서 각각 $102.20 \pm 1.68 \mathrm{pg} / \mathrm{ml}, 76.19 \pm 2.15 \mathrm{pg} / \mathrm{ml}, 62.78 \pm 3.44$ $\mathrm{pg} / \mathrm{ml}$ 로 나타나, $10,100 \mu \mathrm{g} / \mathrm{ml}$ 농도에서 대조군에 비해 유의성 있는(** : $\left.p<0.01,{ }^{* * *}: p<0.001\right)$ 감 소가 나타났다(Fig. 9).

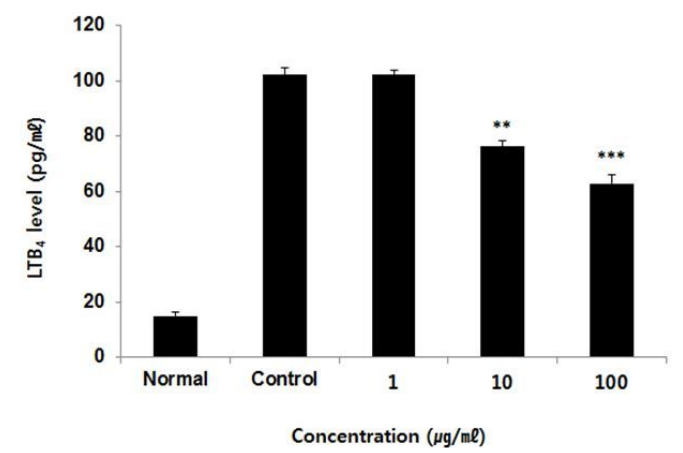

Fig. 9. Effect of FMH on LTB4 level in RAW264.7 cells.

RAW264.7 cells were treated by 1,10 , and 100 $\mu \mathrm{g} / \mathrm{ml}$ of $\mathrm{FMH}$ with $1 \mu \mathrm{g} / \mathrm{ml}$ LPS for $24 \mathrm{~h}$. Treated cells were measured by LTB4 Parameter Assay Kit. The result were presented by the mean \pm S.D from three independent experiments (Significance of results, ${ }^{* *}: \mathrm{p}<0.01,{ }^{* * *}: \mathrm{p}<0.001$ compared to control).

\section{4. 세포 내 유전자 발현량 측정}

1) CCL5

HUVEC 세포 내 CCL5 유전자 발현량을 측정 한 결과, 정상군은 $0.13 \pm 0.05 \%$, 대조군은 $1.00 \pm 0.01 \%$ 로 나타났을 때, $\mathrm{FMH} 1,10,100 \mu \mathrm{g} / \mathrm{ml}$ 에서 각각 $1.04 \pm 0.08 \%, 0.93 \pm 0.08 \%, 0.23 \pm 0.02 \%$ 로 나타나, 100 $\mu \mathrm{g} / \mathrm{ml}$ 농도에서 대조군에 비해 유의성 있는(*** : $\mathrm{p}<0.001$ ) 감소가 나타났다(Fig. 10).

2) Monocyte chemoattractant protein 1 (MCP-1) HUVEC 세포 내 MCP-1 유전자 발현량을 측정 한 결과, 정상군은 $0.10 \pm 0.01 \%$, 대조군은 $1.00 \pm 0.15 \%$ 로 나타났을 때, $\mathrm{FMH} 1,10,100 \mu \mathrm{g} / \mathrm{ml}$ 에서 각각 $0.99 \pm 0.09 \%, 0.79 \pm 0.05 \%, 0.50 \pm 0.04 \%$ 로 나타나, 10 , $100 \mu \mathrm{g} / \mathrm{ml}$ 농도에서 대조군에 비해 유의성 있는 $\left(^{*}: \mathrm{p}<0.05,{ }^{* *}: \mathrm{p}<0.01\right)$ 감소가 나타났다(Fig. 11).

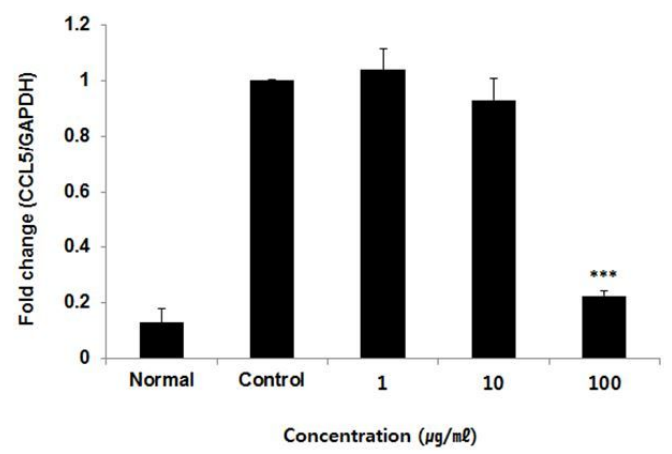

Fig. 10. Effect of FMH on CCL5 mRNA expression levels in HUVEC cells.

HUVEC cells were treated by 1,10 , and $100 \mu \mathrm{g} / \mathrm{ml}$ of FMH with TNF-a for $24 \mathrm{~h}$. CCL5 mRNA expression levels were measured by polymerase chain reaction. The result were presented by the mean \pm S.D from three independent experiments (Significance of results, *** : $p<0.001$ compared to control).

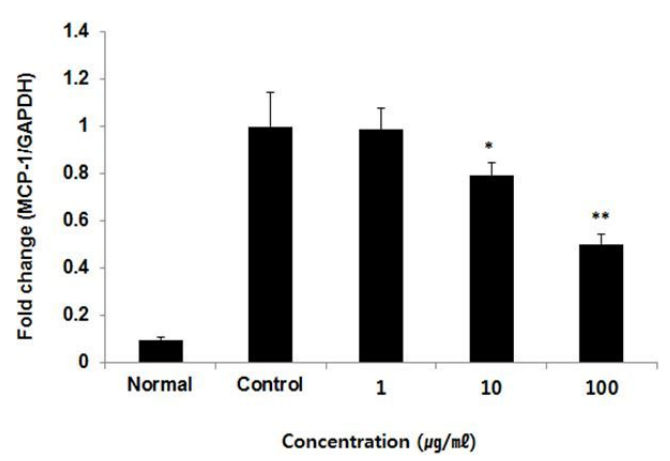

Fig. 11. Effect of FMH on MCP-1 mRNA expression levels in HUVEC cells.

HUVEC cells were treated by 1,10 , and $100 \mu \mathrm{g} / \mathrm{ml}$ of FMH with TNF-a for 24 h. MCP-1 mRNA expression levels were measured by polymerase chain reaction. The result were presented by the mean \pm S.D from three independent experiments (Significance of results, ${ }^{*}: \mathrm{p}<0.05,{ }^{* *}: \mathrm{p}<0.01$ compared to control).

\section{3) CXCL8}

HUVEC 세포 내 CXCL8 유전자 발현량을 측정 
한 결과, 정상군은 $0.10 \pm 0.01 \%$, 대조군은 $1.00 \pm 0.01 \%$ 로 나타났을 때, $\mathrm{FMH} 1,10,100 \mu \mathrm{g} / \mathrm{ml}$ 에서 각각 $1.02 \pm 0.04 \%, 0.98 \pm 0.05 \%, 0.50 \pm 0.03 \%$ 로 나타나, 100 $\mu \mathrm{g} / \mathrm{ml}$ 농도에서 대조군에 비해 유의성 있는 $(* * *$ : $\mathrm{p}<0.001$ ) 감소가 나타났다(Fig. 12).

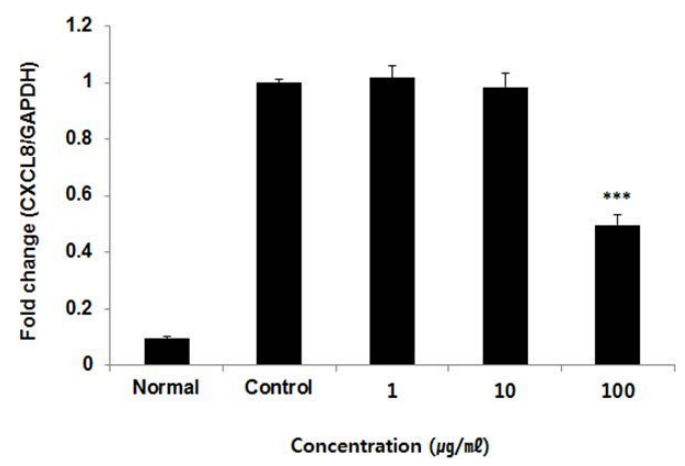

Fig. 12. Effect of FMH on CXCL8 mRNA expression levels in HUVEC cells.

HUVEC cells were treated by 1,10 , and $100 \mu \mathrm{g} / \mathrm{ml}$ of FMH with TNF-a for $24 \mathrm{~h}$. CXCL8 mRNA expression levels were measured by polymerase chain reaction. The result were presented by the mean \pm S.D from three independent experiments (Significance of results, $* * * * p<0.001$ compared to control).

\section{4) $\mathrm{CX} 3 \mathrm{CL} 1$}

HUVEC 세포 내 CX3CL1 유전자 발현량을 측 정한 결과, 정상군은 $0.40 \pm 0.06 \%$, 대조군은 $1.00 \pm 0.02 \%$ 로 나타났을 때, $\mathrm{FMH} 1,10,100 \mu \mathrm{g} / \mathrm{ml}$ 에서 각각 $1.02 \pm 0.03 \%, 0.88 \pm 0.07 \%, 0.60 \pm 0.06 \%$ 로 나타나, 10 , $100 \mathrm{\mu g} / \mathrm{ml}$ 농도에서 대조군에 비해 유의성 있는 $\left.{ }^{*}: \mathrm{p}<0.05,{ }^{* * *}: \mathrm{p}<0.001\right)$ 감소가 나타났다(Fig. 13).

5) Intercellular adhesion molecule 1(ICAM-1)

HUVEC 세포 내 ICAM-1 유전자 발현량을 측정 한 결과, 정상군은 $0.24 \pm 0.12 \%$, 대조군은 $1.00 \pm 0.12 \%$ 로 나타났을 때, $\mathrm{FMH} 1,10,100 \mu \mathrm{g} / \mathrm{ml}$ 에서 각각 $1.13 \pm 0.07 \%, 0.55 \pm 0.01 \%, 0.41 \pm 0.02 \%$ 로 나타나, 10 , $100 \mu \mathrm{g} / \mathrm{ml}$ 농도에서 대조군에 비해 유의성 있는 $\left(* *: p<0.01,{ }^{* * *}: p<0.001\right)$ 감소가 나타났다(Fig. 14)

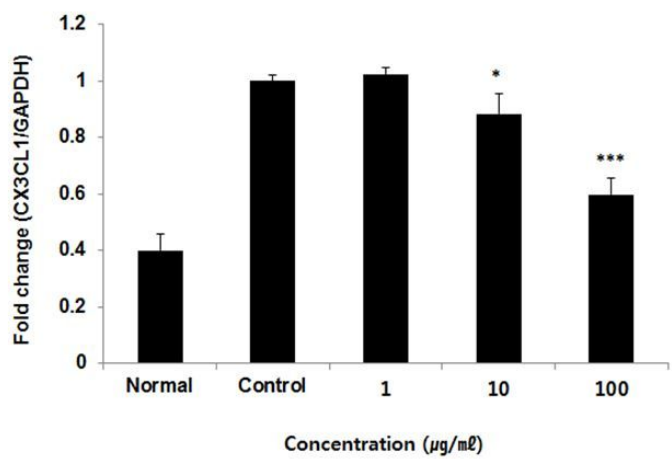

Fig. 13. Effect of FMH on CX3CL1 mRNA expression levels in HUVEC cells.

HUVEC cells were treated by 1,10 , and $100 \mu \mathrm{g} / \mathrm{ml}$ of FMH with TNF-a for 24 h. CX3CL1 mRNA expression levels were measured by polymerase chain reaction. The result were presented by the mean \pm S.D from three independent experiments (Significance of results, ${ }^{*}: \mathrm{p}<0.05,{ }^{* * *}: \mathrm{p}<0.001$ compared to control).

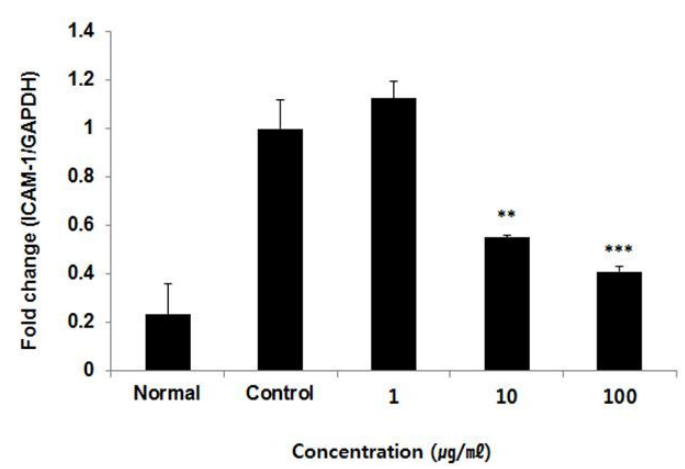

Fig. 14. Effect of FMH on ICAM-1 mRNA expression levels in HUVEC cells.

HUVEC cells were treated by 1,10 , and $100 \mu \mathrm{g} / \mathrm{ml}$ of FMH with TNF- $a$ for $24 \mathrm{~h}$. ICAM-1 mRNA expression levels were measured by polymerase chain reaction. The result were presented by the mean \pm S.D from three independent experiments (Significance of results, $* *: p<0.01, * * *$ : $\mathrm{p}<0.001$ compared to control).

6) Vascular cell adhesion molecule 1(VCAM-1) HUVEC 세포 내 VCAM-1 유전자 발현량을 측정 한 결과, 정상군은 $0.17 \pm 0.11 \%$, 대조군은 $1.00 \pm 0.07 \%$ 


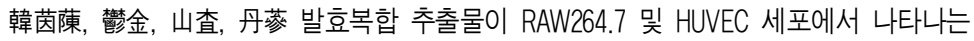
이상지질혈증 관련 염증인자 발현 및 항산화에 미치는 영향

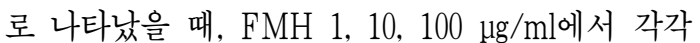
$0.67 \pm 0.10 \%, 0.73 \pm 0.06 \%, 0.42 \pm 0.14 \%$ 로 나타나, 100 $\mu \mathrm{g} / \mathrm{ml}$ 농도에서 대조군에 비해 유의성 있는(* : $\mathrm{p}\langle 0.05)$ 감소가 나타났다(Fig. 15).

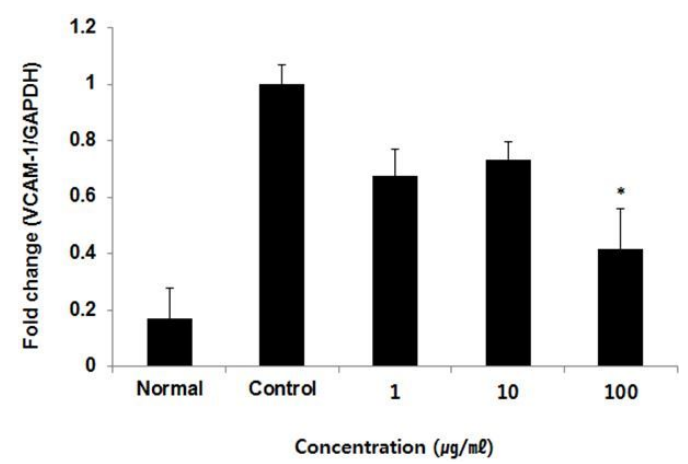

Fig. 15. Effect of FMH on VCAM-1 mRNA expression levels in HUVEC cells.

HUVEC cells were treated by 1,10 , and $100 \mu \mathrm{g} / \mathrm{ml}$ of FMH with TNF- $a$ for 24 h. VCAM-1 mRNA expression levels were measured by polymerase chain reaction. The result were presented by the mean \pm S.D from three independent experiments (Significance of results, * : p $<0.05$ compared to control).

7) Krûppel-like Factor 2(KLF2)

HUVEC 세포 내 KLF2 유전자 발현량을 측정 한 결과, 정상군은 $2.12 \pm 0.22 \%$, 대조군은 $1.00 \pm 0.11 \%$ 로 나타났을 때, $\mathrm{FMH} 1,10,100 \mu \mathrm{g} / \mathrm{ml}$ 에서 각각 $0.74 \pm 0.03 \%, 1.74 \pm 0.09 \%, 2.35 \pm 0.01 \%$ 로 나타나, 10 , $100 \mu \mathrm{g} / \mathrm{ml}$ 농도에서 대조군에 비해 유의성 있는 ${ }^{*}: \mathrm{p}<0.05,{ }^{* *}: \mathrm{p}<0.01$ ) 증가가 나타났다(Fig. 16).

8) Endothelial nitric oxide synthase(eNOS)

HUVEC 세포 내 eNOS 유전자 발현량을 측정 한 결과, 정상군은 $3.65 \pm 0.23 \%$, 대조군은 $1.00 \pm 0.11 \%$ 로 나타났을 때, $\mathrm{FMH} 1,10,100 \mu \mathrm{g} / \mathrm{ml}$ 에서 각각 $0.60 \pm 0.16 \%, 2.01 \pm 0.04 \%, 2.42 \pm 0.01 \%$ 로 나타나, 10 , $100 \mu \mathrm{g} / \mathrm{ml}$ 농도에서 대조군에 비해 유의성 있는 (* $^{*} \mathrm{p}<0.05,{ }^{* *}: \mathrm{p}<0.01$ ) 증가가 나타났다(Fig. 17).

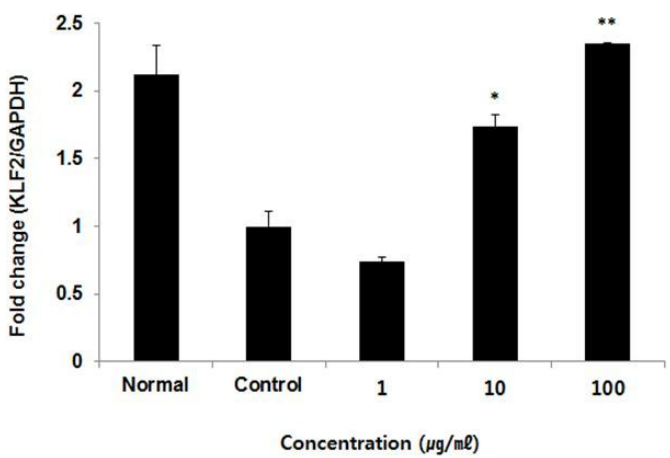

Fig. 16. Effect of FMH on KLF2 mRNA expression levels in HUVEC cells.

HUVEC cells were treated by 1,10 , and $100 \mu \mathrm{g} / \mathrm{ml}$ of FMH with TNF-a for 24 h. KLF2 mRNA expression levels were measured by polymerase chain reaction. The result were presented by the mean \pm S.D from three independent experiments (Significance of results, ${ }^{*}: p<0.05,{ }^{* *}: p<0.01$ compared to control).

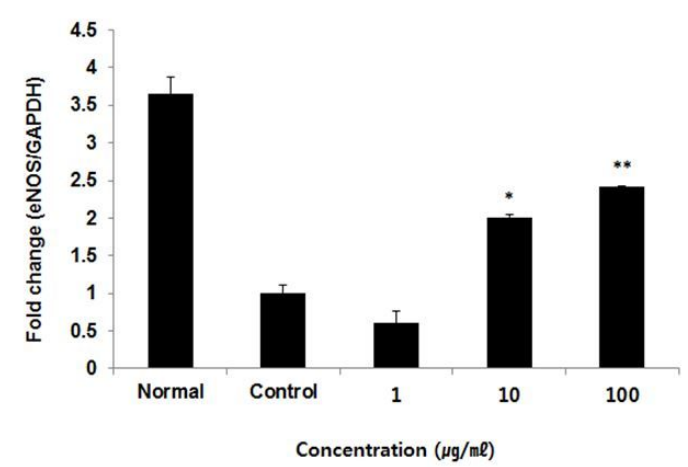

Fig. 17. Effect of FMH on eNOS mRNA expression levels in HUVEC cells.

HUVEC cells were treated by 1,10 , and $100 \mu \mathrm{g} / \mathrm{ml}$ of FMH with TNF-a for 24 h. eNOS mRNA expression levels were measured by polymerase chain reaction. The result were presented by the mean \pm S.D from three independent experiments (Significance of results, ${ }^{*}: p<0.05,{ }^{* *}: p<0.01$ compared to control).

\section{IV. 고 찰}

전 세계적으로 발생하는 연간 약 5700 만 명의 
사망자 중 허혈성 심질환 및 뇌졸중으로 인한 사 망자가 약 1500 만 명 정도 되며, 이는 최근 15 년간 가장 주요한 사망원인이었다 ${ }^{20}$. 선진국에서는 지난 수십 년 동안 심혈관계질환에 의한 사망이 감소하 고 있는 반면, 국내에서는 오히려 급속히 증가하고 있다. 심혈관계질환의 위험인자로는 남자의 경우에 는 고혈압, 흡연, 이상지질혈증으로 확인되었으며 여자는 고혈압, 이상지질혈증, 당뇨병, 흡연의 순서 로 영향을 미치는 것으로 밝혀졌는데, 다른 위험인 자들은 이전보다 감소하거나 잘 조절되고 있는 반 면 식습관이나 운동 같은 생활습관의 악화와 이로 유발되는 혈중 지질 농도의 증가가 심혈관질환의 발병에 중요한 역할을 하고 있다 ${ }^{21}$.

이상지질혈증은 한의학에서 직접적으로 언급되 어 있지는 않지만 비슷한 내용을 찾아볼 수 있는 데, 《靈樞 - 衛氣失常論》에 ‘肥人多, 有膏, 有肉’이 라고 한 것과 《靈樞・五症津液別篇》에 “五穀之津 液, 和合而爲亳, 內滲入于骨空, 補益髓腦而下流于陰 股'22라고 기록되어 있어 高를 이상지질에 대한 언 급으로 유추해볼 수 있다. 이상지질혈증은 津液의 일종으로 水穀에서 來源하고 血中에 들어가 영양 물질이 되는 血脂가 과다하거나 장부의 기능실조 로 대사가 실조되면 발생하며, 痰濁과 血疙로 보고 祛痰 및 化疙시키는 治法을 사용한다 ${ }^{23}$.

발효는 고분자 당이 떨어져 나가며 저분자화되 어 체내흡수율이 증가되게 하는 기전을 가지며 이 로써 생체 이용률을 증가시키는데, 한약의 유효성 분은 대개 고분자 당류로 구성되어있기 때문에 최 근 발효한약이 관심을 모으고 있으며 발효시 원래 의 성질이 변하여 새로운 치료 작용을 기대할 수 있다 ${ }^{24}$. 이에 본 저자는 비교적 안전성이 높은 천연 물 중 기존에 많은 선행연구를 통해 이상지질혈증 치료에 사용되던 청혈플러스 구성약재의 발효 복 합추출물로 연구를 진행하게 되었다.

韓茵随은 利水滲濕藥에 해당하며 性은 微寒하고 味는 苦辛하고 淸濕熱한다. 동맥죽상경화모델 집토 끼에게 한인진전탕액을 복용시킨 결과 혈중 이상
지질상태가 개선되었으며 동맥궁이나 내장병변 보 호작용이 나타났다 25.26 .

鬱金은 活血祛瘀藥에 해당하며 性은 寒하고 味 는 辛苦하고 活血消病, 解鬱社痰시킨다. 동맥죽상 경화모델 집토끼와 흰쥐에게 울금전탕액을 복용시 켰더니 혈중 콜레스테롤이 낮아졌으며, 관상동맥내 막의 지질침착을 감소시켰다 ${ }^{25.26 .}$

山査는 消食藥에 해당하며 性은 微溫하고 味는 酸甘하며 行氣消食散疼작용을 한다. 동맥죽상경화 모델 집토끼의 정맥에 산사추출물을 주사하였더니 혈중 콜레스테롤 저하작용이 있었으며 기관의 콜 레스테롤 침착을 줄여 혈압을 낮추는 역할을 하였 다 ${ }^{25.26}$.

丹蓼은 活血祛疙藥에 해당하며 性은 微寒하고 味는 苦하고 活血祛疙 작용을 한다. 최근엔 관상동 맥경화나 혈전폐색 등에 좋은 치료효과가 있다고 밝혀졌다 ${ }^{25.26}$.

이상지질혈증에 관한 연구에서는 대체로 항산화, 항염증을 같이 진행하게 된다. 이는 이상지질혈증 이 동맥경화를 유발하는 과정에서 산화적스트레스 가 결정적인 역할을 하며 염증반응이 포함되고, 나 아가 노화나 암까지 유발 가능하기 때문이다 ${ }^{27}$.

RAW264.7 세포에서 세포생존율을 측정한 결과 $\mathrm{FMH}$ 농도가 $1,10,100 \mu \mathrm{g} / \mathrm{ml}$ 에서 각각 $106.85 \pm 3.33 \%$, $109.36 \pm 2.43 \%, 103.77 \pm 6.48 \%$ 로 나타났다(Fig. 4A). HUVEC 세포에서 세포생존율을 측정한 결과 $\mathrm{FMH}$ $1,10,100 \mu \mathrm{g} / \mathrm{ml}$ 에서 각각 $99.77 \pm 0.82 \%, 99.75 \pm 1.37 \%$, $99.96 \pm 1.16 \%$ 로 나타났다(Fig. 4B). 이로써 실험이 주로 진행된 농도에서 안전한 것으로 확인되었다. 그리고 두 세포 모두 $\mathrm{FMH} 200 \mu \mathrm{g} / \mathrm{ml}$ 이상의 농도 에서는 $80 \%$ 이하의 생존율을 보였다.

$\mathrm{FMH}$ 에 존재하는 총 polyphenol 함량은 $8.74 \pm 0.30$ $\mathrm{GAE} / \mathrm{g}$ 으로 나타났으며 (Table 2), 총 flavonoid 함 량을 측정한 결과, $1.83 \pm 0.19 \mathrm{mg} / \mathrm{g}$ 으로 나타났다 (Table 3). 이로써 FMH에는 항산화물질이 들어있 는 것을 알 수 있다.

$\mathrm{FMH}$ 의 농도를 $1,10,100,1,000(\mu \mathrm{g} / \mathrm{ml})$ 로 희석 


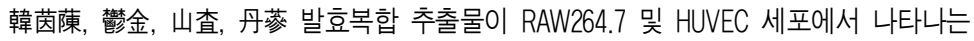
이상지질혈증 관련 염증인자 발현 및 항산화에 미치는 영향

시키고 DPPH assay와 ABTS assay를 시행하였더 니 DPPH radical 소거능과 ABTS radical 소거능 은 농도 의존적인 증가를 보였다(Fig. 2, 3). 이 결 과로 볼 때 $\mathrm{FMH}$ 가 항산화능을 나타내는 것으로 사료된다.

RAW264.7 세포 내 NO생성량을 측정한 결과, 실험한 모든 농도에서 대조군에 비해 유의성 있는 감소가 나타났다(Fig. 5). IL-1ß 생성량을 측정한 결과 $10,100 \mu \mathrm{g} / \mathrm{ml}$ 농도에서 대조군에 비해 유의 성 있는 감소가 나타났고(Fig. 6), IL-6 생성량은 모든 농도에서 대조군에 비해 유의성 있는 감소가 나타났으며(Fig. 7), TNF-a 생성량은 10, $100 \mu \mathrm{g} / \mathrm{ml}$ 농도에서 대조군에 비해 유의성 있는 감소가 나타 났다(Fig. 8). LTB4는 10, $100 \mu \mathrm{g} / \mathrm{ml}$ 농도에서 대 조군에 비해 유의성 있는 감소가 나타났다(Fig. 9). 따라서 $\mathrm{FMH}$ 는 세포 내 항염증 작용을 하는 것으 로 사료된다.

GAPDH는 유전자 발현량 측정 실험에서 이 유 전자의 발현량을 기준으로 측정하고자 하는 유전 자 발현량을 상대정량 하는데 쓰이며 ${ }^{28}$, Chemokine 은 백혈구유주 및 염증반응의 주요한 역할을 하며 혈관신생을 매개하여 종양성장이나 전이에 관여하는 작은 단백질로, 본 실험에서 측정한 CCL5, MCP-1, CXCL8, CX3CL1은 chemokine에 속한다 ${ }^{29}$. ICAM-1, $\mathrm{VCAM}-1$ 은 세포접합분자로, 동맥경화의 초기 과정 중 염증반응을 유발한다 ${ }^{30}$.

HUVEC 세포 내 CCL5 유전자 발현량을 측정 한 결과 $\mathrm{FMH} 100 \mu \mathrm{gg} / \mathrm{ml}$ 농도에서 대조군에 비해 유의성 있는 감소가 나타났다(Fig. 10). 세포 내 $\mathrm{MCP}-1$ 유전자 발현량은 $10,100 \mu \mathrm{g} / \mathrm{ml}$ 농도에서 대조군에 비해 유의성 있는 감소가 나타났으며 (Fig. 11). CXCL8 유전자 발현량은 $100 \mu \mathrm{g} / \mathrm{ml}$ 농 도에서 대조군에 비해 유의성 있는 감소가 나타났 다(Fig. 12). CX3CL1 유전자 발현량은 10, $100 \mu \mathrm{g} / \mathrm{ml}$ 농도에서 대조군에 비해 유의성 있는 감소가 나타 났으며 (Fig. 13), ICAM-1 유전자 발현량은 10, 100 $\mu \mathrm{g} / \mathrm{ml}$ 농도에서 대조군에 비해 유의성 있는 감소
가 나타났고(Fig. 14) VCAM-1 유전자 발현량은 $100 \mu \mathrm{g} / \mathrm{ml}$ 농도에서 대조군에 비해 유의성 있는 감소가 나타났다(Fig. 15). KLF2 유전자 발현량은 $10,100 \mu \mathrm{g} / \mathrm{ml}$ 농도에서 대조군에 비해 유의성 있는 증가가 나타났고(Fig. 16), eNOS는 10, $100 \mu \mathrm{g} / \mathrm{ml}$ 농도에서 대조군에 비해 유의성 있는 증가가 나타 났다(Fig. 17). 따라서 FMH는 세포 내 항염증 작 용을 하는 것으로 사료된다.

본 연구에서는 한인진, 울금, 산사, 단삼 복합추 출물을 발효시켜 실험하였는데, 이전의 비발효 복 합추출물 연구 실험과는 세포상태, 사용된 시약, cytokine 측정에 사용되는 antibody 등의 차이가 있어 그 결과를 절대적 수치로 비교하기는 불가능 하다. 하지만 발효가 유효성분의 흡수를 용이하게 한다는 사실과, 발효를 이용하여 약재의 더 좋은 효능을 얻었다는 보고가 지속적으로 나오고 있는 것을 고려한다면 본 연구의 좋은 결과에 발효가 긍정적인 역할을 하였을 것으로 생각해 볼 수 있 다. 추후 발효군과 비발효군의 효능 비교를 위해 같은 조건 안에서 통제되는 두 군에 대한 연구가 추가적으로 필요할 것으로 보인다.

종합하여 보면, $\mathrm{FMH}$ 는 산화적 손상 및 이상지 질혈증으로 인한 염증반응과 이로써 발생하는 죽 상동맥경화증, 허혈성 심질환, 뇌졸중 등 심뇌혈관 계질환의 예방과 치료에 유효할 것으로 보인다. 다만, 본 실험에서는 세포 연구만을 다루어 혈중 cholesterol level의 측정이 이루어지지 않아 이상지질혈증 자 체의 개선 효능을 명확히 판단하기는 어렵다. 따라 서 향후 in vivo실험을 통해 이러한 부분을 명확히 밝힐 필요가 있다고 사료된다.

\section{V. 결 론}

한인진, 울금, 산사, 단삼 발효복합추출물 $(\mathrm{FMH})$ 의 항염증 및 항이상지질 효능을 객관적으로 검증 하기 위하여 마우스 대식세포인 RAW264.7 세포와 인간 탯줄 정맥 내피 세포인 HUVEC 세포를 통해 
다양한 인자를 확인한 결과 다음과 같은 결론을 얻었다.

1. $\mathrm{FMH}$ 는 $8.74 \pm 0.30 \mathrm{GAE} / \mathrm{g}$ 의 polyphenol 함량과 $1.83 \pm 0.19 \mathrm{mg} / \mathrm{g}$ 의 flavonoid 함량을 나타내었으 며, DPPH 및 ABTS radical 소거능을 농도의존 적으로 증가시켰다.

2. $\mathrm{FMH}$ 는 NO와 IL-6 생성량을 모든 농도에서 대 조군에 비해 유의성 있게 감소시켰으며, IL- $1 \beta$, TNF-a, LTB4 생성량을 10, $100 \mu \mathrm{g} / \mathrm{ml}$ 농도에 서 대조군에 비해 유의성 있게 감소시켰다.

3. FMH는 CCL5, CXCL8, VCAM-1 유전자 발현 량을 $100 \mu \mathrm{g} / \mathrm{ml}$ 농도에서 대조군에 비해 유의성 있게 감소시켰으며, MCP-1, CX3CL1, ICAM-1 유전자 발현량을 $10,100 \mu \mathrm{g} / \mathrm{ml}$ 농도에서 대조 군에 비해 유의성 있게 감소시켰다. 또한 $\mathrm{KLF} 2$ 와 eNOS 유전자 발현량을 $10,100 \mu \mathrm{g} / \mathrm{ml}$ 농도 에서 대조군에 비해 유의성 있게 증가시켰다.

이상의 결과를 종합해 볼 때, 발효복합추출물은 항산화효능과 RAW264.7 세포 및 HUVEC 세포에 서 항염증 및 항이상지질혈증 효능이 실험적으로 규명되었다. 추후 in vivo 실험을 통한 혈중지질평 가 및 관련 연구가 필요하리라 사료된다.

\section{참고문헌}

1. Statistics Korea. 2016 Death statistics. Korea: Korea development institute; 2016.

2. Korean Academy of Medical Sciences \& Korea Centers for Disease Control and Prevention. Guideline for Dyslipidemia in Primary Care. Seoul: Guideline Information Center; 2016.

3. National Oriental Medical Department of Heart Internal Medicine. Oriental neurocirculatory Internal Medicine. $3^{\text {rd }}$ edition. Seoul: Gunja publishing company; 2011, p. 184-5.
4. Cha BS. Step to Internal Medicine Endocrinology. $4^{\text {th }}$ edition. Seoul: Jungdam publishing company; 2018, p. 389.

5. Cho SY, Choi HJ, Choi JW, Ha WH, Lee SJ. Antiobesity and Antihyperlipidemia of Red Crab Shells in Sprague Dawley Rat. J Chitin Chitosan 2010:15(3) :156-63.

6. An JJ, Cho HK, Kim YS, Park SA, Seol IC, Yoo HR. The Effects of Gamijihwang-tang(GJT) on Hyperlipidemia in Rats. $J$ Int Korean Med 2009:30(2) :338-54.

7. Lee WC, Oh KH. Neuroprotective Effect Yanggyuksanhwatang on Cerebral Infarction Induced by MCAO in Hyperlipidemic Rats. $J$ Int Korean Med 2006; 27(4):915-26.

8. Choi SH, Kim JM, Seol IC, Son CG. Study for Trends of Antihyperlipidemic Studies using Herbal Plants. J Int Korean Med 2010:31(3):448-56.

9. Han JM, Im HJ, Jo HK, Lee JS, Lee SJ, Son CG, et al. ACE Reduces Metabolic Abnormalities in a High-Fat Diet Mouse Model. eCAM 2015; 2015(352647):8.

10. Kim HT, Kim YS, Seol IC, Yoo HR. Effects of an Extract of Artemisiae Capillaris, Curcumae Longae, and Crataegi Fructus(IUS) on Antihyperlipidemia and Anti-oxidation in $\mathrm{db} / \mathrm{db}$ Mouse Model. J Int Korean Med 2016:37(3) :467-83.

11. Cho HK, Kim YS, Ryu JY, Seol IC, Yoo HR. The Effects of Artemisiae Iwayomogii Herba, Curcumae Radix, and Aurantii Fructus Immaturus Complex Extract (ACA) on Dyslipidemia-related Factor Expression and Anti-oxidation in HepG2 Cells. J Int Korean Med 2017:38(3):367-75.

12. Cha JY, Cho HK, Kim YS, Seol IC, Yoo HR. Inhibition of gene associated with Dyslipidemia and Antioxidative Effect of Artemisia iwayomogi, 


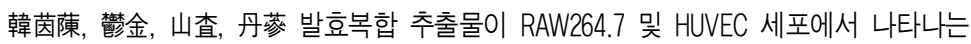
이상지질혈증 관련 염증인자 발현 및 항산화에 미치는 영향

Curcumae Radix and Raphani Semen(ACR) on HepG2 cell model. $J$ Korean Med 2017;38(3) $: 43-58$.

13. Cho HK, Jung ES, Kim YS, Seol IC, Yoo HR. Antioxidant and Anti-dyslipidemic Effect of Artemisiae iwayomogii Herba, Curcumae longae Radix, and Plantaginis Semen Complex Extract(ACP) on HepG2 Cells. J Physiol \& Pathol Korean Med 2018;32(1):13-23.

14. Lee CS, Woo MS. progress in oriental medicine clinical treatment of common diseases. $1^{\text {st }}$ edition. Hanam: China chinese medicine publishing company; 1991, p. 81.

15. Textbook Compilation Committee of Oriental pathology. Oriental pathology. $2^{\text {nd }}$ edition. Seoul: Oriental medicine cultural company; 2008, p. 94, 113.

16. Kim HJ, Kwon OJ, Lee AR, Roh SS, Seo YB. Protective effects of Gastrodia rhizoma and steamed\& fermented Gastrodiae rhizoma with anti-oxidant efficacy and suppression of $\mathrm{NF} \kappa \mathrm{B}$ signaling pathway on LPS-induced liver injury. J Appl Biol Chem 2016;59(3):179-88.

17. Feng XJ, Oh DS, Roh SS, Seo YB. Lipid Improvement Effect of Fermented Cynanchi wilfordii Radix in Hyperlipidemia Rats : Erratum. Kor J Herbology 2015;30(6) :83-91.

18. Kang DG. Effects of the Fermented Extract Using the Leaves of Pinus densiflora on Hyperlipidemia Rats. $J$ Physiol \& Pathol Korean Med 2003:17(1):140-5.

19. Cho HK, Choi KE, Kim YS, Seol IC, Yoo HR. Hypolipidemic and Anti-oxidant Effects of Chunghyl Plus in Type II Diabetic Mice Model. J Physiol \& Pathol Korean Med 2016; 30(3) :164-76.

20. World Health Organization. Global Health Estimates 2016: Deaths by Cause, Age, Sex, by Country and by Region, 2000-2016. Geneva: WHO; 2018.

21. Committee for Guidelines for Management of Dyslipidemia. 2015 Korean Guidelines for Management of Dyslipidemia. J Lipid Atheroscler 2015;4(1) :61-92.

22. Yang YG. The translation of Hwangjenaegyung. $1^{\text {st }}$ edition. Seoul: Iljoongsa; 1991, p. 296-7, 416.

23. Bang HJ, Hong Y, Kang YH, Tak US. The Oriental Medicine Review of Dyslipidemia. The journal of east-west medicines 1995:20(1):25-36.

24. Han HS. Effect of Fermented Artemisiae Argyi Folium on Human Hepatoma Cell Line HepG2 Activity. Kor J Herbology 2013;28(3):107-13.

25. Herbal medicine Compilation Committee of College of Oriental Medicine. Herbal medicine. $2^{\text {nd }}$ edition. Seoul: Younglimsa; 2010, p. 369, 411-2, 453, 458.

26. Go BS. The encyclopedia of Chinese Herbal medicine. $2^{\text {nd }}$ edition. Daebukseong: Shinmoonpung; 1974, p. 216, 303-4, 1604, 2639.

27. Hao G, Le GW, Li W, Shi YH, Yang RL. Increasing Oxidative Stress with Progressive Hyperlipidemia in Human: Relation between Malondialdehyde and Atherogenic Index. $J$ Clin Biochem Nutr 2008;4(3):154-58.

28. Barber RD, Clark BJ, Coleman RA, Harmer DW. GAPDH as a housekeeping gene: analysis of GAPDH mRNA expression in a panel of 72 human tissues. Physiol Genomics 2005:21(3): 389-484.

29. Christopherson K, Hromas R. Chemokine Regulation of Normal and Pathologic Immune Responses. Stem Cells 2001;19(5):388-96.

30. Harrison's Internal Medicine Editorial Board of the Korean Society of Internal Medicine. Harrison's Principles of Internal Medicine. 15th edition. Seoul: MIP; 2003, p. 1420. 